\title{
Perceptions on Urbanization Impact on the Hinterlands: A Study of Khon Kaen City, Thailand
}

\author{
Maniemai Thongyou ${ }^{1}$, Thanapauge Chamaratana ${ }^{2}$, Monchai Phongsiri ${ }^{1} \&$ Bounthavy Sosamphanh ${ }^{3}$ \\ ${ }^{1}$ Center for Research on Plurality in the Mekong Region, Faculty of Humanities and Social Sciences, Khon \\ Kaen University, Thailand \\ ${ }^{2}$ Institute of Skill Development Regional VI, Ministry of Labour and Social Welfare, Thailand \\ ${ }^{3}$ Faculty of Social Sciences, Lao National University, Lao PDR. \\ Correspondence: Maniemai Thongyou, Center for Research on Plurality in the Mekong Region, Faculty of \\ Humanities and Social Sciences, Khon Kaen University, Thailand. E-mail: maniemai@gmail.com
}

Received: June 20,2013 Accepted: April 25, $2014 \quad$ Online Published: May 30, 2014
doi:10.5539/ass.v10n11p33 $\quad$ URL: http://dx.doi.org/10.5539/ass.v10n11p33

\begin{abstract}
This research article aims to study the impact of urbanization on its hinterlands, by focusing on the perceptions of the household heads in the hinterlands of a small city, which is the major type of the cities in the Mekong region. Khon Kaen city in the northeast region of Thailand was selected as a case study. A questionnaire survey was conducted with a sample of 409 households in 35 villages in the city's hinterlands, defined as the areas of 5 kilometres lying further from a ring road surrounding the city. Data were analysed by descriptive statistics and mean ranking. The research found that the top ten most favorable impacts were on better access to health and educational services, better employment and educational opportunities, women's decision making power and social status, as well as positive impact on local government. As for the negative impacts of urbanization, pre-marriage sexual relationship, co-habitation and inappropriate dressing of village youths were identified as major problems. Apart from youth's problems, other social problems namely gambling and drug addiction were identified, as well as household economic problems including shortage of farm lands, higher household expenditure and debts. Among the top ten highest ranks of negative impacts, only one environmental problem, namely noise pollution, was identified. However, it is remarkable that environmental sector contained the highest numbers of unfavorable impacts that had mean value less than three. In other words, among the seven sectors explored, namely the household economy, the village economy, the society, the political and administration, the ideology and culture, the women and youths and the environment, the research found that environmental sector got the highest number of negative items of urbanization impacts. Based on a Multiple Regression Analysis, the research found that household heads' age $(B e t a=0.127)$ and monthly income (Beta $=-0.175$ ) were the factors that influenced their perceptions on the impacts with the $\mathrm{R}^{2}=0.073$.
\end{abstract}

Keyword: urbanization, hinterlands, impact, perception, Khon Kaen, Thailand

\section{Introduction}

Urbanization, defined as the process by which an increasing proportion of the world's population lives in urban areas, is a major change taking place globally (Waugh, 1995). The urban global tipping point was reached in 2007 when for the first time in history over half of the world's population were living in urban areas; around 3.3 billion people . It is estimated that $60 \%$ of the world's population will be urbanized by 2030 (The International Federation of Surveyors, 2010). Asia and the Pacific is the second least urbanized region of the world, with only $43 \%$ of the population living in urban areas in 2010 . However, the region has the second fastest urban population growth rate, at the average of 2.0 per cent per annum (2005-2010) (UNDP, 2010).

Concern of rapid urbanization extends beyond the challenges faced within urban areas to the impact on its hinterlands, as rural and urban economy and social life are becoming increasingly intertwined, due to various factors including the growth of peri-urban areas, migration, lengthening commodity chain, an extraction of resources from rural areas for consumption and processing in urban areas, and investment of income earned from urban areas back in agriculture. Changes in the hinterlands range from urban expansion to the decline of agriculture, new employment opportunities, and environmental problems. Understanding the impact of urbanization on the hinterlands has significant implications, because the ecological, economic and social 
functions performed in this area affect both the city and the countryside. Sustainable growth of the city depends on healthy and balanced relationship with its hinterlands, and vice versa (Allen, 2003).

Urban hinterlands can be defined as the landscape interface between town and country, or also as the transition zone where urban and rural uses, interact and often clash. Alternatively, it can be viewed as a landscape type in its own right, one forged from an interaction of urban and rural land uses. The documented impact of urbanization on rural hinterlands include, for example, changes in ecological balance, loss of agricultural land, land speculation, changes in farming practices, livelihoods and life-styles, and pollution (Brockherhoff, 2000). Urbanization also has many positive impacts on the hinterlands such as greater income and job opportunities, better access to education and health care and other services. Such impacts are expected to increase, particularly in the hinterlands areas of small and medium-sized cities, which form the major characteristics of urban areas in the Mekong Region (Kammeier, 2003).

Objective of the Research: The objective of this research article is to examine the impact of urbanization on the hinterlands, based on a study of a fast growing medium sized city in the northeast region Thailand. The article is structured in two main parts. First, it outlines the basic characteristics of the households in the hinterlands, and second, it analyses the impacts of urbanization on the hinterlands' household and village economy, society, and environment, based on the perceptions of the householders.

In this research, the city of Khon Kaen was purposely selected as a case study. The city is the administrative centre of Khon Kaen province, one of the twenty provinces in the northeast region of Thailand. Khon Kaen city is one of Thailand's major provincial cities and is the regional centre for education, finance and banking, health services, transportation and government administration. The city of Khon Kaen, here defined as Khon Kaen municipality, has a population of 111,776 persons in 2011, covering the area of 46 square kilometres (Khon Kaen Municipality, 2012). There had been attempts to set up a small town in the area since early 1780s by the king of Siam to consolidate people and settlements, and to establish tighter connection with Bangkok, but this was not very successful. The town had been moved six times until finally set up in the present location in 1879 . Khon Kaen has become more established since the 1960s when it was purposely selected a growth centre for the largest and poorest region of Thailand, for the green revolution and industrialization under the economic growth and modernization model of rural development during the cold war period. The city has since then gradually developed amidst the vast rural areas dominated by rice cultivation and a few upland cash crops on the arid areas, and become the real centre of administration of the province and the whole northeast region.

\section{Method}

This article is part of a larger research project which employed a mixed methodology using both qualitative and qualitative research methods. However, the data and analysis presented in this article is mainly based on a questionnaire survey, with supplementary explanation based on in-depth interview.

In this research, Khon Kaen hinterlands is defined as the areas of 5 kilometres lying further from a ring road surrounding Khon Kaen city, where there were altogether 12 sub-districts and 35 villages and 10,476 households, based on 2011 election data base of the Ministry of Interior. A sample size of 409 households was determined by using F Test of Variance Proportion in Multiple Regression/Correlation analysis (MCA) (Cohen, 1988). A systematic sampling method was used to draw sample households from the 2011 election data, from household number 1 to 10,476, yielding the 409 households proportionately-to-size distributed in 35 villages in 12 sub-districts around Khon Kaen city.

Structured interview schedule was used to collect data during November - December 2011. Descriptive statistics, including percentage, standard deviation, means, minimum and maximum values and mean raking were used to analyse the data.

\section{Results and Discussion}

\subsection{The Respondents and the Hinterland Households}

The household respondents in this survey were mostly women (66.0 per cent of 409 households) at the average age of 51.1 years old, while the average age of all household members was 39.6 years old. Most of the respondents (75.1 per cent) were born in the house they were living at the time of the interview, married (72.4 per cent), and received primary level of education (64.3 per cent). In terms of the education of the respondents, most were farmers (32.5 per cent), followed by unemployed, waiting for jobs, and housewife (20.8 per cent). Other common occupations include trading and entrepreneurial activities (17.1 per cent), workers (13.9 per cent), employees, government officials and public enterprise and students. Most of the respondents (76.8 per cent) worked in their own village or other nearby villages ( 76.8 per cent). Another 15.2 per cent worked in Khon Kaen 
city (Table 1).

The majority of the sample households were located in the sub-district municipal areas (67 per cent of 409 households) at not exceeding 10 kilometers from the city (67.5 per cent). The average distance from the households to the city was 9.5 kilometers. Most of the sample households (56.7 per cent) spent 15-30 minutes travelling to the city, at the average time of 24.7 minutes. The most common means of transportation was bus (41.6 per cent), followed by private car or truck (35.7 per cent).

The majority of the sample households had an income at more than 20,000 Baht per month. The average income was 23,075 Baht. The income disparity of the sample households was remarkably high, with the minimum income of 500 baht and the maximum income of 140,000 baht per month. With regards to land holding, most of the sample households owned small pieces of farm land at not more than 5 rai (Note 1) (56.2 per cent). The average land size per household was 6.48 rai (Table 1). Most of the lands were used for rice farming, at the average size of 5.4 rai per household.

Table 1. Characteristics of respondents and hinterland households

\section{Characteristics of Respondents and Households}

\section{Percent}

\section{Occupation of the respondents}

$\begin{array}{lr}\text { Peasant/farmer } & 32.5\end{array}$

$\begin{array}{lr}\text { Merchant/own business } & 17.1\end{array}$

$\begin{array}{lr}\text { Worker } & 13.9\end{array}$

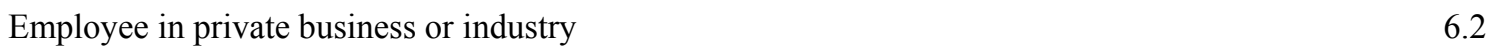

$\begin{array}{ll}\text { Government official/public enterprise official } & 6.1\end{array}$

$\begin{array}{lr}\text { Student } & 3.4\end{array}$

$\begin{array}{lr}\text { Unemployed/housewife/disabled/others } & 20.8\end{array}$

Total

\section{Place of work of the respondents}

$\begin{array}{lr}\text { In own or nearby village } & 76.8\end{array}$

In the city (Khon Kaen municipality areas) 15.2

$\begin{array}{ll}\text { Other districts/other places } & 4.8\end{array}$

$\begin{array}{ll}\text { Urban fringe } & 3.2\end{array}$

$\begin{array}{lr}\text { Total } & 100.0(409)\end{array}$

Monthly income of the households

$\begin{array}{lr}\text { Less than 10,000 Baht } & 22.5\end{array}$

$\begin{array}{lr}\text { Between 10,000 - 20,000 Baht } & 38.4\end{array}$

$\begin{array}{lr}\text { More than 20,000 Baht } & 39.1\end{array}$

Total

$(\mathrm{X}=23,075.8 \mathrm{Baht}, \mathrm{SD} .=20382.09, \mathrm{Min}=500.0 \mathrm{Baht}, \mathrm{Max}=140,000.0$ Baht $)$

\section{Land holding of the households}

Less than 5 rai

Between 5-10 rai

More than 10 rai

Total

$(\mathrm{X}=6.48 \mathrm{rai}, \mathrm{SD} .=9.02, \mathrm{Min}=0.0 \mathrm{rai}, \mathrm{Max}=72.5 \mathrm{rai})$ 


\subsection{Perceived Impact of Urbanization on the Hinterlands}

\subsubsection{Level of Impact of Urbanization by Sector}

This research explored the impact of urbanization in 7 sectors, namely the household economy, the village economy, the society, the political and administration, the ideology and culture, the women and youths, and the environment (Rondinelli, 1985; Potter and Unwin, 1989). Even though most of the sample household perceived that urbanization does not have any impact to their household and community, it is remarkable that over one-fifth $(21 \%)$ felt that urbanization has negative impacts on the hinterlands' environment - the highest percentage for the situation getting worsened. Despite these negative impacts, urbanization was perceived of as generating positive impacts on the political and administrative aspects of the hinterlands, as well as on the ideology and culture.

Table 2. Level of impact of urbanization as perceived by hinterland households $(n=409)$

\begin{tabular}{lcccccc}
\hline \multirow{2}{*}{$\begin{array}{c}\text { Type of Impact } \\
\text { (by Sector) }\end{array}$} & $\begin{array}{c}\text { Getting } \\
\text { much } \\
\text { worsened }\end{array}$ & $\begin{array}{c}\text { Getting } \\
\text { worsened }\end{array}$ & $\begin{array}{c}\text { No } \\
\text { impact }\end{array}$ & $\begin{array}{c}\text { Getting } \\
\text { better }\end{array}$ & $\begin{array}{c}\text { Getting much } \\
\text { better }\end{array}$ & Total \\
\hline On household economy & - & 2.0 & 80.4 & 17.4 & 0.2 & 100 \\
On village economy & - & 1.7 & 78.7 & 19.6 & - & 100 \\
On society & - & 9.5 & 76.5 & 14.0 & - & 100 \\
On politic and & - & 5.1 & 38.1 & 56.1 & 0.7 & 100 \\
administration & & & & & & \\
On ideology and culture & 0.7 & 10.5 & 47.7 & 36.2 & 4.9 & 100 \\
On women and youths & - & 4.9 & 84.1 & 10.8 & 0.2 & 100 \\
On environment & 0.7 & 20.3 & 68.5 & 10.5 & - & 100 \\
\hline
\end{tabular}

\subsubsection{Level of Impact of Urbanization by Item}

\subsubsection{Positive Impacts}

The impact of urbanization on the hinterlands as perceived by household heads was analysed by using mean ranking of each item of the perceived impacts in the seven themes above. Each theme contains 5-12 items. Analysis of mean ranking indicated that the most favourable impact was on health care services (mean $=3.86$ out of 5.00). This is not surprising, given the fact that two large and modernized hospitals, one being the Northeast regional hospital and the other Khon Kaen University hospital, are located in the city and, with the health welfare policy covering all Thai citizens, people can get medical services at almost free of charge. Other favourable impacts ranking at the top six were related to increased women's rights and empowerment. These included employment opportunity for women in the village (mean $=3.85$ ), women's participation in family's decision (mean $=3.84$ ), women's participation in village's decision (mean $=3.78$ ) and women's social status $($ mean $=3.77)$. It should be noted here that 66 percent of the respondents in this research were women at the average age of 51.1 years old (Table 1). Though this might be the reason for a bias towards the favour of women rights items, it also reflected what mature women in the hinterlands valued most.

Another highly favourable impact was increased education opportunities (mean $=3.82$ ). Young people in the hinterlands had more access to higher education due to more convenient transportation to the city where vocational colleges and universities were located. More rural hinterland parents could afford sending their children to college because they had more diversified employment opportunities (mean $=3.59$ ). In addition, market oriented agriculture provided income that made possible the investment in children's education. It is argued here that giving highest possible education to children has become the most prominent value among rural parents around the city of Khon Kaen (Note 2), though turning the value into real practice is not an easy task as young people in the hinterlands were unfortunately torn by the dark side of modernization, as we shall discuss further.

Households in the hinterlands also had positive attitude towards urban impact on local government management, particularly on its investment in infrastructure development (mean $=3.64)$ and in increased people's participation 
in local government organization (mean $=3.58$ ). It is remarkable that the respondents seemed to have linked the benefits of the country's partial administrative decentralization policy from central government to local governments with urbanization.

The top 10 mean ranking indicating the most favourable impact of urbanization as perceived by rural households are as follows: (see all ranking items in Table 3)

Access to health services $($ mean $=3.86)$

Employment opportunity for women in village $($ mean $=3.85)$

Women's participation in family's decision (mean $=3.84$ )

Education opportunities (mean $=3.82$ )

Women's participation in village's decision (3.78)

Women's social status (mean $=3.77$ )

Employment opportunities of villagers $($ mean $=3.72)$

Local government's investment in infrastructure development (mean $=3.64$ )

Employment opportunities of household members (mean $=3.59$ )

People's participation in local government organization $($ mean $=3.58)$

\subsubsection{Negative Impacts}

Urbanization has both positive and negative impacts. In what follows, we will discuss the negative impacts as perceived by hinterland households. In contrast to the most favourable impacts that were centred around women's empowerment, the negative attitudes towards the impacts were targeted on youths' problems. Urbanization has most worsened the following problems of young people in the village: pre-marriage sexual relationship $($ mean $=2.10$ ), pre-marriage co-habitation $($ mean $=2.11$ ), inappropriate dressing $($ mean $=2.18$ ), and youth gangs and inappropriate activities, e.g. motorcycle racing and tattooing (mean $=2.19)$. Following these top four most negative impacts, the following two items were similarly social problems concerning people at all ages, including young people, namely drug addiction ( mean $=2.44)$ and gambling $($ mean $=2.40)$ problems.

The top environmental problem indicated in this survey was noise pollution (mean $=2.51$ ). Our in-depth interview revealed several causes, including noises from traffics particularly motorcycles, bars and karaoke, factories, and construction machines. It should be noted that environmental theme contains the highest proportion of items with unfavourable impacts, including decreased soil quality, solid wastes from the city, new built environment created environmental problems such as floods, village water and air quality, decreased natural food sources, decreased access to natural resources and public lands (Table 3).

Other items in the top ten ranking of undesired impact of urbanization were related to village and household economy, including shortage of farmland $($ mean $=2.54)$, household expenditure $($ mean $=2.57)$, and household debts $($ mean $=$ 2.57).

The top 10 mean ranking indicating the most unfavourable impacts of urbanization as perceived by rural households are as follows: (see all ranking items in Table 3)

Pre-marriage sexual relationship of village youths (mean $=2.10)$

Pre-marriage co-habitation of village youths (mean $=2.11$ )

Inappropriate dressing of village youths (mean $=2.18)$

Youth gangs and inappropriate activities (mean $=2.19)$

Gambling problem $($ mean $=2.40)$

Drug addiction problem $($ mean $=2.44)$

Noise pollution in village $($ mean $=2.51)$

Shortage of farmland of villagers $($ mean $=2.54)$

Household expenditure $($ mean $=2.57)$

Household debts (mean $=2.57)$.

The mean raking of all impact items are presented in Table 3 below. 
Table 3. Mean value of impact of urbanization as perceived by hinterland households $(n=409)$

\begin{tabular}{|c|c|c|c|}
\hline Type of Impact (by Item) & Mean & $\begin{array}{l}\text { Standard } \\
\text { Deviation }\end{array}$ & Rank \\
\hline Economic Impact - Household Economy & 3.16 & 0.422 & \\
\hline Household's access to agricultural markets in town & 3.44 & 0.712 & 23 \\
\hline Household income from agricultural activities & 3.21 & 0.624 & 31 \\
\hline Household income from non-agricultural activities & 3.39 & 0.624 & 27 \\
\hline Employment opportunities of household members & 3.59 & 0.669 & 9 \\
\hline Household expenditure & 2.57 & 0.829 & 60 \\
\hline Household debts & 2.70 & 0.682 & 56 \\
\hline Shortage of farmland & 2.76 & 0.620 & 50 \\
\hline Changes in consumption pattern & 3.04 & 0.617 & 39 \\
\hline Changes in daily lifestyle & 3.40 & 0.641 & 26 \\
\hline Overall standard of living of householders & 3.47 & 0.737 & 20 \\
\hline Economic Impact - Village Economy & 3.18 & 0.426 & \\
\hline Access to agricultural market in town of villagers & 3.56 & 0.643 & 12 \\
\hline Income from agricultural activities of villagers & 3.44 & 0.725 & 24 \\
\hline Income from non-agricultural activities of villagers & 3.57 & 0.614 & 11 \\
\hline Employment opportunities of villagers & 3.72 & 0.627 & 7 \\
\hline Household expenditure of villagers & 2.72 & 0.856 & 53 \\
\hline Household debts of villagers & 2.57 & 0.690 & 59 \\
\hline Shortage of farmland of villagers & 2.54 & 0.727 & 61 \\
\hline Land rent and land price in village & 3.48 & 0.952 & 16 \\
\hline Changes in agricultural mode of production & 3.13 & 0.728 & 36 \\
\hline Contribution of agriculture to village economic system & 3.16 & 0.777 & 34 \\
\hline Overall standard of living of villagers & 3.42 & 0.744 & 25 \\
\hline Social Impact & 3.04 & 0.483 & \\
\hline Mutual confidence and trust in the village & 3.07 & 0.856 & 38 \\
\hline Community solidarity and social cohesion & 3.22 & 0.824 & 30 \\
\hline Sense of security & 3.18 & 0.936 & 33 \\
\hline Education opportunities & 3.82 & 0.674 & 4 \\
\hline Access to health services & 3.86 & 0.672 & 1 \\
\hline Incidence of crime & 2.62 & 0.765 & 58 \\
\hline Drug addiction problem & 2.44 & 0.742 & 63 \\
\hline Gambling problem & 2.40 & 0.725 & 64 \\
\hline Economic disparities within village & 2.70 & 0.652 & 54 \\
\hline Social disparities within village & 2.70 & 0.652 & 55 \\
\hline Conflicts within village & 2.74 & 0.605 & 51 \\
\hline Overall quality of life and well-being & 3.48 & 0.823 & 17 \\
\hline Political and Administration Impact & 3.52 & 0.606 & \\
\hline
\end{tabular}




\begin{tabular}{|c|c|c|c|}
\hline Type of Impact (by Item) & Mean & $\begin{array}{l}\text { Standard } \\
\text { Deviation }\end{array}$ & Rank \\
\hline Quality of state and local services in meeting villagers' demands & 3.53 & 0.747 & 14 \\
\hline Adequacy of state and local services in meeting villagers' demands & 3.47 & 0.780 & 19 \\
\hline State and local government's investment in infrastructure & 3.64 & 0.796 & 8 \\
\hline People's participation in local government organization & 3.58 & 0.721 & 10 \\
\hline Villagers get equal services from government agencies & 3.53 & 0.807 & 15 \\
\hline Conflicts between local government and Khon Kaen city & 3.14 & 0.615 & 35 \\
\hline Local government has more working capacity & 3.45 & 0.782 & 21 \\
\hline Urban bias policy creates problems to villages & 3.04 & 0.833 & 40 \\
\hline Cultural and Ideological Impact & 3.34 & 0.760 & \\
\hline Participation in religious and cultural activities of village & 3.48 & 0.894 & 18 \\
\hline Religious faith of villagers & 3.44 & 0.827 & 22 \\
\hline Awareness and recognition of local culture and heritage & 3.32 & 0.839 & 28 \\
\hline Confidence and faith in rural way of life & 3.27 & 0.812 & 29 \\
\hline Confidence and faith to maintain agricultural activities & 3.11 & 0.792 & 37 \\
\hline Impact on Women and Youth & 3.06 & 0.403 & \\
\hline Employment opportunity for women in village & 3.85 & 0.554 & 2 \\
\hline Women's participation in family's decision & 3.84 & 0.617 & 3 \\
\hline Women's participation in village's decision & 3.78 & 0.611 & 5 \\
\hline Women's social status & 3.77 & 0.618 & 6 \\
\hline Young adults' employment is in line with their education and skill & 3.55 & 0.641 & 13 \\
\hline Pre-marriage sexual relationship of village youths & 2.10 & 0.742 & 68 \\
\hline Pre-marriage co-habitation of village youths & 2.11 & 0.720 & 67 \\
\hline Inappropriate dressing of village youths & 2.18 & 0.800 & 66 \\
\hline Youth gangs and inappropriate activities & 2.19 & 0.742 & 65 \\
\hline Village youths doing public service activities & 2.90 & 0.856 & 45 \\
\hline Environmental Impact & 2.89 & 0.571 & \\
\hline Dependence on natural resources for food & 2.89 & 0.793 & 46 \\
\hline Opportunities to benefit from natural resources & 2.92 & 0.812 & 44 \\
\hline Access to public lands & 2.96 & 0.753 & 43 \\
\hline Quality of water resources & 2.78 & 0.953 & 48 \\
\hline Quality of air in village & 2.85 & 0.909 & 47 \\
\hline Noise pollution in village & 2.51 & 0.814 & 62 \\
\hline Quality of soil for agriculture & 2.68 & 0.839 & 57 \\
\hline Quantity of solid waste from Khon Kaen city & 2.73 & 0.757 & 52 \\
\hline Management of solid waste from Khon Kaen city & 3.19 & 0.904 & 32 \\
\hline New construction obstructs access to farmlands & 3.02 & 0.752 & 41 \\
\hline New construction creates environmental problems in village & 2.77 & 0.738 & 49 \\
\hline Overall quality of natural resources and environment & 2.98 & 0.972 & 42 \\
\hline
\end{tabular}




\subsubsection{Factors Influencing Perceptions on Impacts of Urbanization}

A Multiple Regression Analysis was used to identify the most important factors that influence the perceptions of the household's head on the impact of urbanization o the hinterlands. The research found that household heads' age (Beta $=0.127$ ) and monthly income (Beta $=-0.175)$ were the factors that influenced their perceptions on the impacts with the $\mathrm{R}^{2}=0.073$ (Table 4). Factors that were included in the Multiple Regression Analysis but were found not to have significant influence on the perceptions were average age of household members, monthly income of all household members, land holding of households, length of stay in the village, number of close neighbors, number of household members working in the city, number of household members studying in the city, number of household members working in city/town in other provinces, number of household members being members of a political party, size of land sold to city people during the last 10 years, proportion of non-agricultural activities with markets in the city, proportion of agricultural produce sold to markets in the city, and proportion of change in type of agricultural production to serve markets in the city.

Table 4. Factors influencing perceptions of household's heads on the impact of urbanization on the hinterlands in Khon Kaen

\begin{tabular}{lccc}
\hline Independent variables & b & Beta & Sig \\
\hline Age of household head & 0.150 & 0.127 & $0.041^{*}$ \\
Monthly income of households head & 0.000 & -0.175 & $0.009^{*}$ \\
\hline$R^{2}=0.073$
\end{tabular}

$\mathrm{R}^{2}=0.073 \quad \mathrm{~F}=2.054 \quad$ Sig of $\mathrm{F}=0.011 \quad \mathrm{n}=409$

\section{Conclusion}

In this article, we have investigated the perceived impacts of urbanization on the hinterlands in a regional urban center in Thailand. Analysis of mean ranking indicated that the top ten most favorable impacts of urbanization were on better access to health and educational services, better employment and educational opportunities for men and women, women's decision making power and social status, as well as positive impact on local government and governance. As for the negative impacts of urbanization, pre-marriage sexual relationship and co-habitation and inappropriate dressing of village youths were identified. Apart from youth's problems, other social problems such as gambling and drug addiction were identified, as well as household economic problems such as shortage of farm lands, higher household expenditure and debts. Among the top ten highest ranks of negative impacts, only one environmental problem, namely noise pollution, was identified. However, it is remarkable that environmental impacts contained the highest numbers of unfavorable impacts that had mean value less than three. In other words, among the seven sectors explored, namely the household economy, the village economy, the society, the political and administration, the ideology and culture, the women and youths and the environment, the research found that the sector that got wide-spread negative impacts of urbanization, as perceived by hinterland households, was the environmental sector.

\section{References}

Allen, A. (2003). Environmental Planning and Management of the Peri-urban Interface: Perspective on an Emerging Field. Environment and Urbanization, 15(1), 135-147. http://dx.doi.org/10.1177/095624780301500103

Barkey, D. L., Henri M., \& Bao S. (1996). Identifying "Spread" versus "Backwash" Effects in Regional Economic Areas: A Density Functions Approach. Land Economics, 72(3), 336-357. http://dx.doi.org/10.2307/3147201

Boye, T. B. (2004). Urbanization: An Environmental Force to be Reckoned with. Population Reference Bureau. Retrieved January 12, 2011, from http://www.prb.org/articles/2004

Brockherhoff, M. P. (2000). An Urbanizing World. Population Bulletin, 55(3), 3-44.

Cohen, J. (1988). Statistical Power Analysis for the Behavioural Science (2nd ed.). New Jersey: Lawrence Erlbaum Associates.

Hoggart, K. (Ed.). (2005). The City's Hinterland: Dynamism and Divergence in Europe's Peri-urban Territories. Hants: Ashgate.

Kammeier, H. D. (2003). Rural Urban Sub-regional Linkages in the Mekong Region: A Holistic Approach to Development and Poverty Reduction. Manila: Asian Development Bank. 
Khon Kaen Municipality. (2012). Khon Kaen Municipality Population and Area Data. Retrieved July 9, 2012, from http://www.kkmuni.go.th/

Potter, R. B., \& Unwin, T. (1989). The Geography of Urban-rural Interaction in Developing Countries. London and New York: Routledge.

Redman, C. L., \& Jones, N. S. (2004). The Environment, Social and Health Dimensions of Urban Expansion, Population Environment Research Network, Cyberseminar Urban Expansion: The Environmental and Health Dimension, 29 November - 15 December, 2004. Retrieved from http://www.PopulationEnvironmentResearch.org/seminar

Rondinelli, D. A. (1985). Applied Methods of Regional Analysis: The Spatial Dimension of Development Policy. Boulder: Westview.

Simon, D. (2008). Urban Environments: Issues on the Peri-Urban Fringe. Annual Review of Environment and Resources, 33, 167-185. http://dx.doi.org/10.1146/annurev.environ.33.021407.093240

The International Federation of Surveyors. (2010). Rapid Urbanization and Mega Cities: The Need for Spatial Information Management. Copenhagen.

Torrey B. (2004). Urbanization: An Environmental Force to be Reckoned with, Population Reference Bureau. Retrieved January 12, 2011, from http://www.prb.org/articles/2004

UN Habitat. (n. d.). Retrieved January 26, 2011, from http://www.unhabitat.org/content.asp? typeid $=19 \&$ catid $=465 \&$ cid $=2375$

UNDP. (2010). United Nations Population Division World Population Prospects: The 2010 Revision. World Urbanization Prospects: The 2009 Revision. Retrieved July 6, 2012, from http://www.unescap.org/stat/data/syb2011/I-People/Urbanization.asp

Van den Berg, L. M., Van Vijik, M. S., \& Van Hoi, P. (2003). The Transformation of Rural Life in Hanoi. Environment and Urbanization, 15(1), 35-51. http://dx.doi.org/10.1177/095624780301500122

Waugh, D. (1995). Geography: An integrated approach. Surrey, Thomas Nelson and Sons Ltd.

World Bank. (1997). Environmental Assessment Sourcebook, No 19. rai.

\section{Notes}

Note 1. Ra $i$ is a unit of area measurement in Thailand: 1 acre $=2.5$ rai; 1 hectare $=6.25$ rai.

Note 2 . This survey result was verified by qualitative research using in-depth interview and group interview with village leaders and household heads in 4 villages around Khon Kaen City in May-June 2012.

\section{Copyrights}

Copyright for this article is retained by the author(s), with first publication rights granted to the journal.

This is an open-access article distributed under the terms and conditions of the Creative Commons Attribution license (http://creativecommons.org/licenses/by/3.0/). 